\title{
RELATION BETWEEN CHEMICAL COMPOSITION OF GRATELOUPIA DORYPHORA (MONTAGNE) HOWE, GYMNOGONGRUS GRIFFITHSIAE (TURNER) MARTIUS, AND ABIOTIC PARAMETERS
}

\author{
Paulo Nelo Medeiros Perfeto
}

Recebido em 5/5/97. Aceito em 11/3/98

\begin{abstract}
RESUMO - (Relação entre composição química de Grateloupia doryphora (Montagne) Howe, Gymnogongrus griffithsiae (Turner) Martius e parâmetros abióticos). Foi estudado em Grateloupia doryphora e Gymnogongrus griffithsiae a variação sazonal de seus compostos químicos, estabelecendo uma relação com os parâmetros físico-químicos da água do mar. Durante o inverno foram detectados valores altos de proteína nas espécies estudadas, com $28,88 \% \mathrm{em} G$. doryphora e $26,68 \% \mathrm{em} G$. griffithsiae, correspondendo ao período de concentração máxima de amônio no ambiente marinho. A variação no conteúdo de carboidratos apresentou relação inversa à de proteínas. Os valores máximos de $54,72 \% \mathrm{em} G$. doryphora e de $55,36 \% \mathrm{em} \mathrm{G}$. griffithsiae, ocorreram no verão, correlacionados positivamente com salinidade e temperatura da água do mar. Os conteúdos de lipídeos foram baixos em ambas as espécies. Em G. doryphora os valores variaram entre 0,81 e 1,30\% e em G. griffithsiae, de 0,71 a $1,50 \%$ do peso seco, mostrando relação direta com a quantidade de nitrogênio na água do mar. O conteúdo máximo de cinzas, fósforo e potássio ocorreu no outono e inverno, respectivamente com $11,85 \%, 0,20 \%$ e 1,27 \% em G. doryphora e $14,46 \%, 0,14 \%$ e 1,41 \% em G. griffithsiae.
\end{abstract}

Palavras-chave: algas, proteínas, carboidratos, lipídeos, cinzas, nitrogênio, fósforo, potássio

\begin{abstract}
Relation between chemical composition of Grateloupia doryphora (Montagne) Howe, Gymnogongrus griffithsiae (Turner) Martius, and abiotic parameters). In Grateloupia doryphora and Gymnogongrus griffithsiae the seasonal variation of their chemical compounds was studied, establishing a relation with the physical and chemical properties of seawater. High values of proteins in the studied species were detected during the winter, $28.88 \%$ in G. doryphora and $26.68 \%$ in G. griffithsiae, corresponding to the maximum period of ammonium concentration in the marine environment. The variation in carbohydrates content showed an inverse relation with the proteins, with a maximum of $54.72 \%$ in $G$. doryphora and of $55.36 \%$ in G. griffithsiae, both in summer, positively correlated with salinity and temperature of sea water. Lipids content was low in both species. In $G$. doryphora the values ranged between 0.81 and $1.30 \%$ and, in $G$. griffithsiae, from 0.71 to $1.50 \%$ of dry weight, showing a direct relation with the amount of nitrogen in the seawater. The maximum content of ashes, phosphorus and potassium occurred in autumn and winter, respectively, with $11.85 \%, 0.20 \%, 1.27 \%$ in G. doryphora , and $14.46 \%, 0.14 \%, 1.41 \%$ in G. griffithsiae.
\end{abstract}

Key words: algae, proteins, carbohidrates, lipids, ashes, nitrogen, phosphorus, potassium

'Departamento de Oceanografia, Universidade do Rio Grande, Caixa Postal 474, CEP 96201-560, Rio Grande, RS, Brasil 


\section{Introduction}

Benthic marine algae normally present seasonal variations in their chemical composition. Studies on natural populations (Mouradi-Givernaud et al.1993) and on unialgal culture (Macler \& Zupan 1991; Vergara et al. 1993) showed the influence of the abiotic factors on the physiology and chemical compounds of these plants.

The variations on the concentration of dissolved nutrients, temperature and salinity of sea water influence on the content of the organic and inorganic compounds (Gagné \& Mann 1981; Macler \& West 1987), on the growth rate (Chapman \& Lindley 1980; Salinas \& Valdes 1993), and on the morphology of a species (Mshigeni 1979; Mouradi-Givernaud et al. 1992).

Information about abiotic parameters are fundamental for cultivation and management of algae, making it possible the handling of the abiotic conditions to improve growth, production and chemical composition (Fredriksen \& Ruenes 1989; Santelices 1991).

Grateloupia doryphora, a producer of sulfated galactans (Baeza \& Matsuhira 1977), and Gymnogongrus griffithsiae, a source of carrageenans (Saito \& Oliveira F ${ }^{\circ}$ 1990), are species of potential economical importance which grow on the jetty of Rio Grande, RS, Brazil.

This paper aims to relate the seasonal variation of the algal chemical composition and some environmental parameters during one year.

\section{Material and methods}

Grateloupia doryphora and Gymnogongrus griffithsiae were collected monthly, during one year, on the west Jetty of Rio Grande, RS, Brazil (Fig. 1) at a station previously chosen due to its easy access, higher density and relatively greater algal diversity.

The values which represent the thalli length of $G$. doryphora and G. griffithsiae, are the average $(\mathrm{n}=10)$ obtained by measurements of randomly chosen samples thalli.

The algal material was cleaned in running tap water and later in distilled water, oven dried overnight at $80^{\circ} \mathrm{C}$, ground, frozen and stored in plastic bags at $15^{\circ} \mathrm{C}$ negative.

Samples of sea water were obtained weekly at the same place of algae collection, for nutrient analysis and salinity determination. The water was pre-filtered in the site by means of a phytoplankton net and carried to the laboratory in polyethylene bottles, then filtered in a $0.45 \mathrm{~mm} \pm 0.02 \mathrm{~mm}$ Millipore, and frozen at $15^{\circ} \mathrm{C}$ negative.

Total nitrogen was obtained by the Micro-Kjeldhal method (A.O.A.C. 1980) and the equivalent in proteins was estimated by a standard factor 6.25 . The Phenolsulfuric colorimetric method (Dubois et al. 1956) was used to measure carbohydrates. Lipids were determined after extraction with petroleum ether in Soxhlet method (A.O.A.C. 1980).

For phosphorus and potassium determination, ash content was obtained by calcination at $420-480^{\circ} \mathrm{C}$, followed by acid treatment. The reactive phosphorus was estimated by the colorimetric method using vanadomolibdate reagent (Standard 


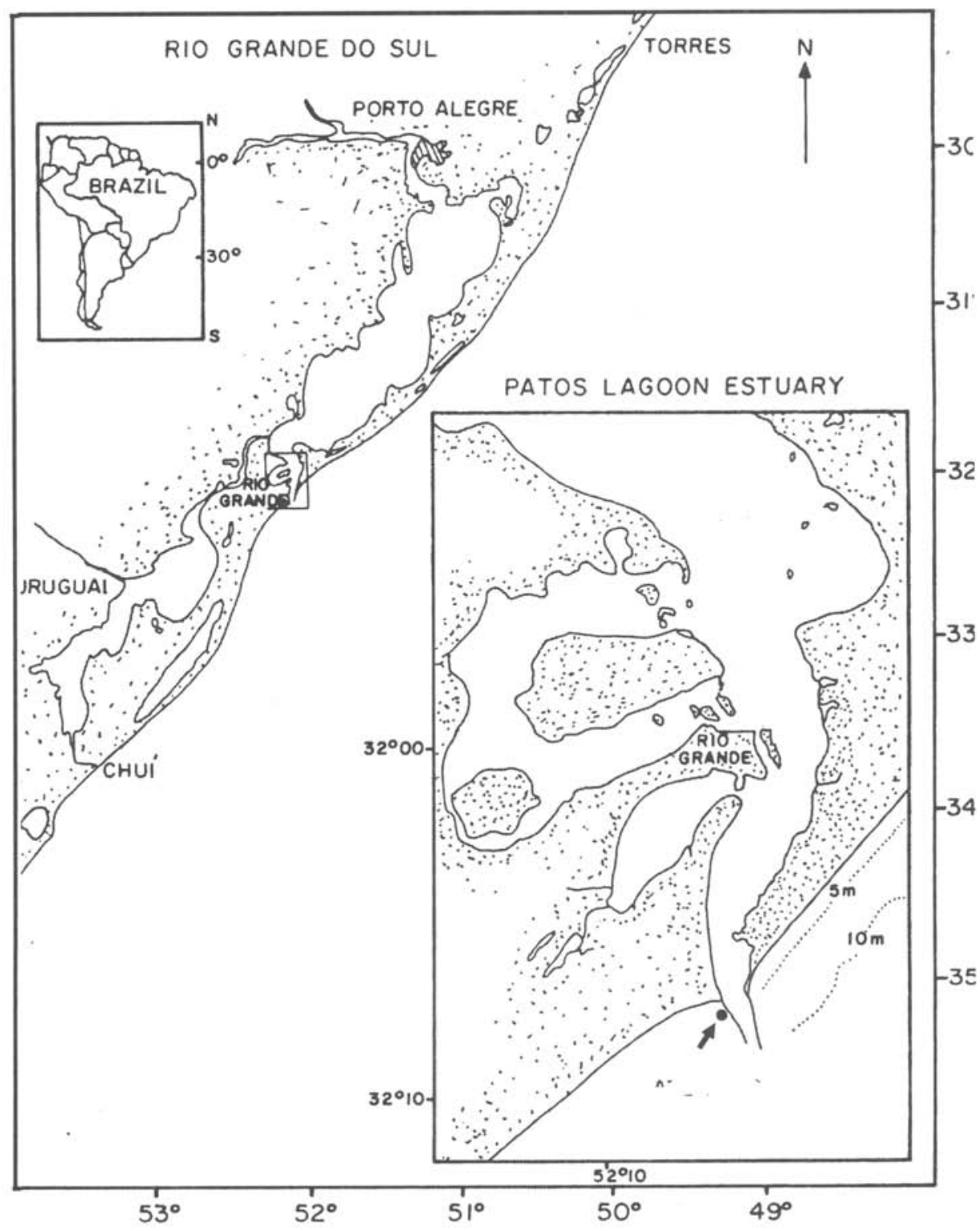

Figure 1. Map of the "Lagoa dos Patos" estuarine area; arrow point show the location of algae and seawater sample site. 
Methods 1989) and the potassium concentration by flame emission spectroscopy (Ohlweiler 1974). Nitrate and phosphate were determined according to Strickland \& Parson (1972), and the ammonium according to Solorzano (1969). The salinity was estimated by Knudsen's titulometric method (Strickland \& Parson 1972), and the temperature was measured in situ by a mercury thermometer.

All chemical analysis were done in duplicate for each sample and the values of chemical composition of algae are given as percentage of the dry matter, and accepting values with a maximum $5 \%$ difference.

\section{Results}

Seawater analysis - Seawater temperature varied from 13.0 to $15.6^{\circ} \mathrm{C}$ in winter, reaching the highest value $\left(25.5^{\circ} \mathrm{C}\right)$ in March. Salinity oscillated between 25.08 and $32.13 \%$ in summer, and $9.03 \%$ in winter. Nitrate concentrations showed highest values in autumn, with a maximum content of $6.16 \mathrm{mM}$ in May; however, it decreased in summer, with a minimum of $2.47 \mathrm{mM}$ in March. The highest and the lowest ammonium concentrations occurred in winter and summer respectively, with 12.49 $\mathrm{mM}$ and $1.17 \mathrm{mM}$ contents. Phosphate reached a maximum during the autumn, with $1.531 \mathrm{mM}$ in April, and a minimum in spring, with $0.296 \mathrm{mM}$. Potassium showed low concentration at the end of autumn and throughout the winter, with values varying between 0.025 and $0.078 \mathrm{mg} / \mathrm{ml}$, but increasing during the summer (Fig. 2).

Algal chemical composition - Protein contents in $G$. doryphora increased during the autumn and winter, decreasing in spring with the minimum value of $22.90 \%$ in December. Carbohydrates contents were lower during autumn and winter, with a minimum of $41.82 \%$ in August. Its concentration increased from spring on, reaching the maximum percentage of $54.72 \%$ during the summer. Lipids concentrations varied little during the year, with low values oscillating between 0.81 and $1.30 \%$. The maximum ashes contents occurred in May, with values of $11.85 \%$, and decreased during spring and summer, with a minimum value of $6.98 \%$ in February (Fig. 3).

In $G$. griffithsiae, the highest protein indexes occurred during the winter, with maximum of $26.68 \%$ in September, and the minimum of $19.96 \%$ in November. Carbohydrates contents were minimum during the spring, $46.20 \%$ in September, and maximum in January, with value of $55.36 \%$. Lipids values were low, varying from 0.71 to $1.50 \%$. The concentration of ashes oscillated between 11.25 and $14.46 \%$ (Fig. 4).

High potassium contents were registered during autumn and winter, with 1.06 and $1.27 \%$ and decreased during the spring and summer months, when the values varied between 0.16 and $0.33 \%$. The highest concentration of phosphorus in the tissues was registered at the end of autumn with $0.20 \%$ in June, remaining high during the winter. The lower concentration of this element was displayed in summer, with minimum values of $0.075 \%$ in January (Fig. 5).

Potassium contents were high during the autumn and winter, with a maximum of $1.41 \%$ in May and low in spring, a minimum of $0.21 \%$ in December. Low values 


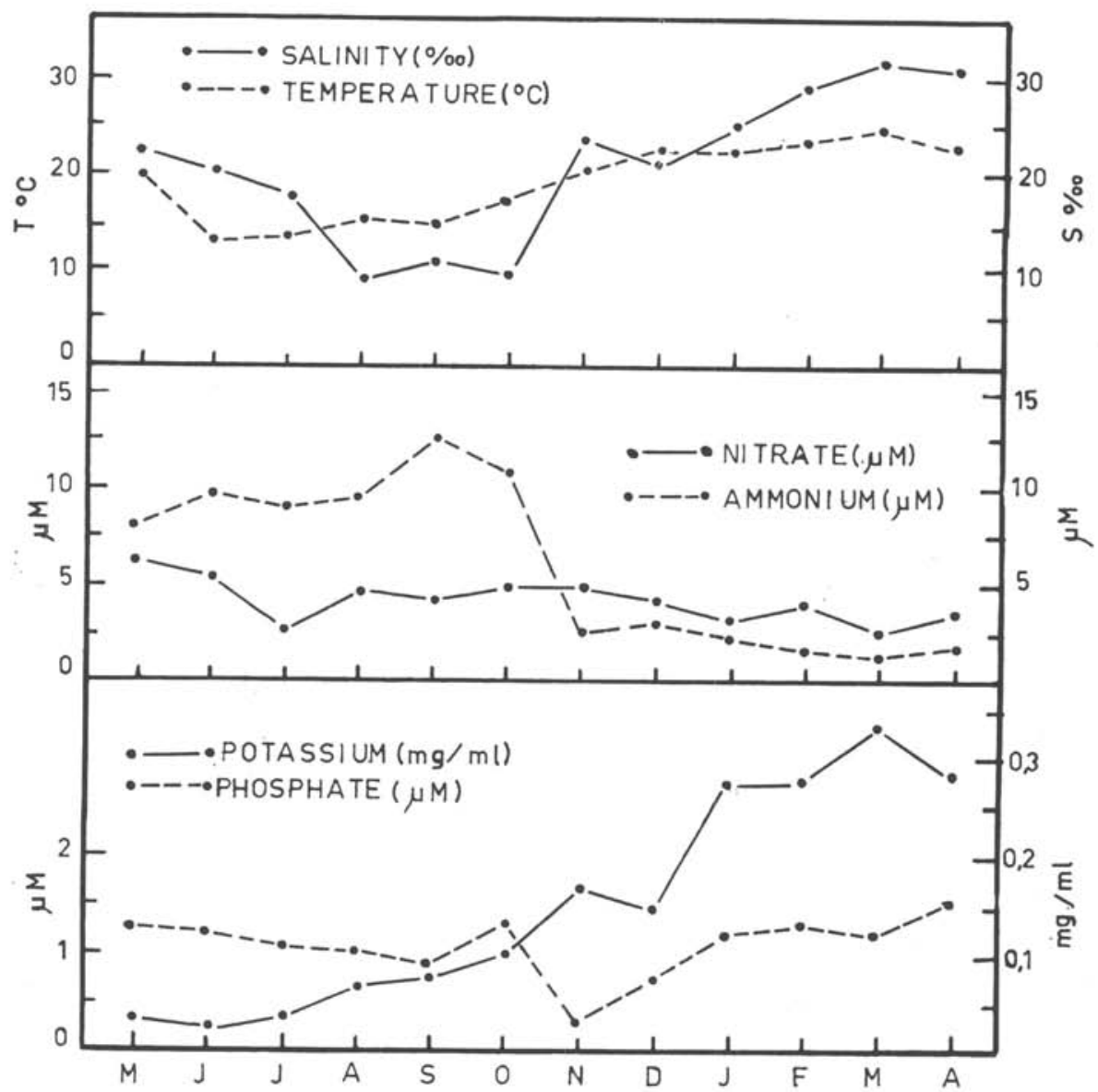

months

Figure 2. Seasonal variation in the physical and chemical parameters of seawater, on the West Jetty of Rio Grande, RS, from May 1988 to April 1989.

of phosphorus in the tissue were found during the year, with a maximum of $0.14 \%$ and a minimum of $0.08 \%$ (Fig. 5).

Analysis of the variation in thalli length along a year, enables us to distinguish the maximum and minimum period of algal growth. The thalli length of G. doryphora reached a maximum size of $33 \mathrm{~cm}$ in February. The length variation of G. griffithsiae thalli was small, between 1 and $4 \mathrm{~cm}$. In this algae the maximum size occurred in July. A secondary peak of thalli growth was observed during summer (Fig. 6). 


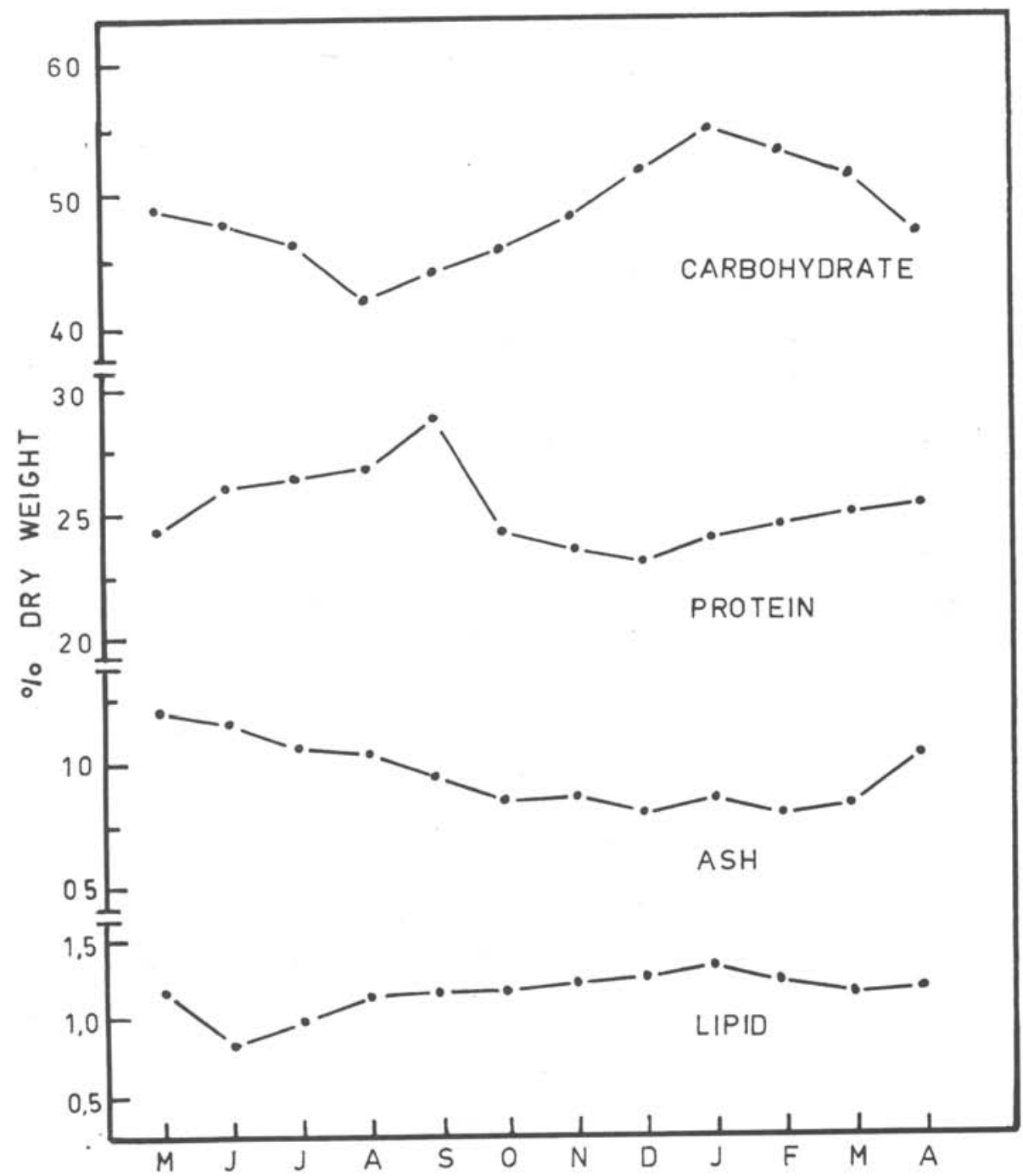

Figure 3. Seasonal yariation in percentage of dry weight of organic compounds and ash in Grateloupia doryphora. 


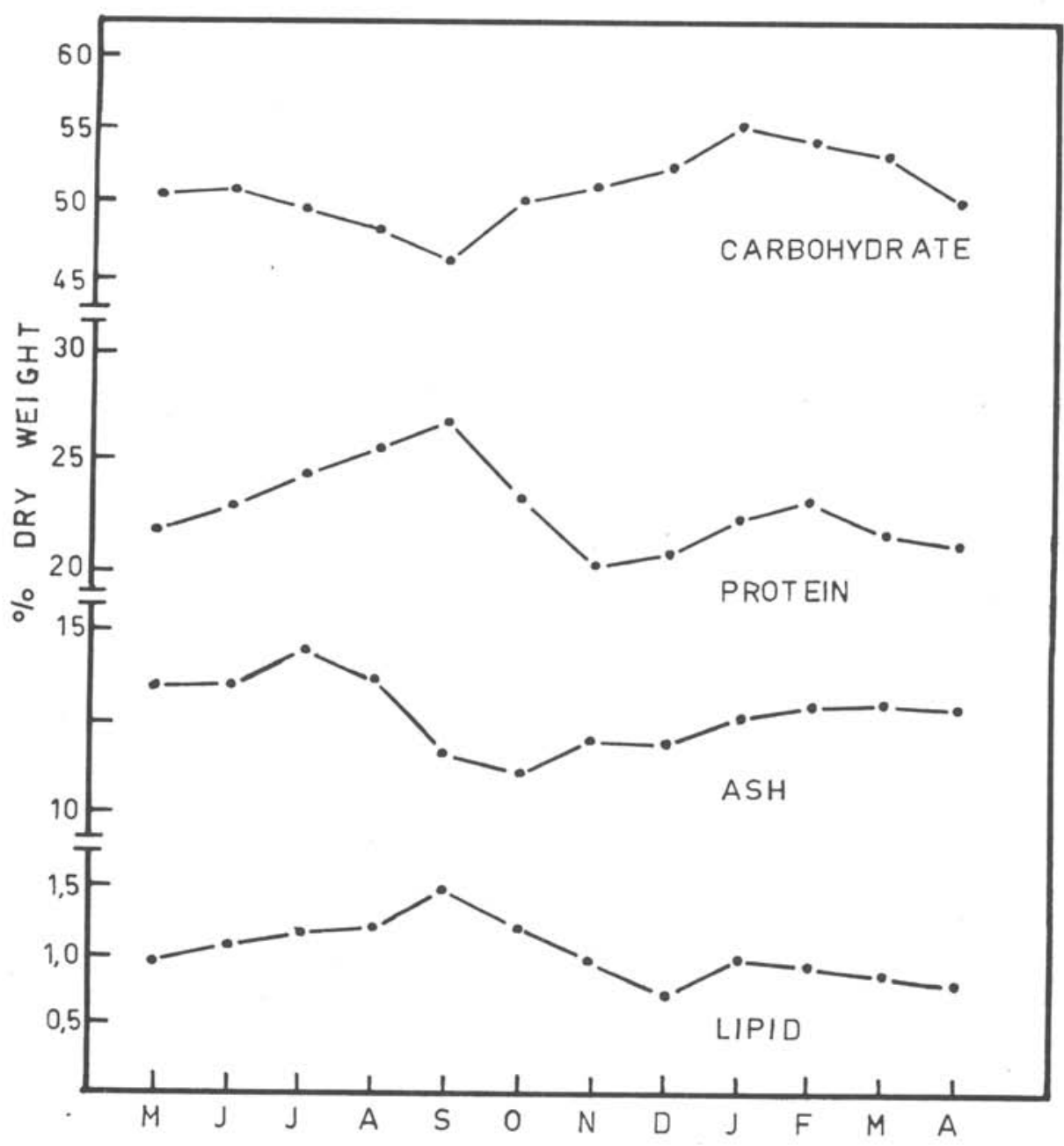

months

Figure 4. Seasonal variation in percentage of dry weight of organic compounds and ash in Gymnogongrus griffithsiae. 


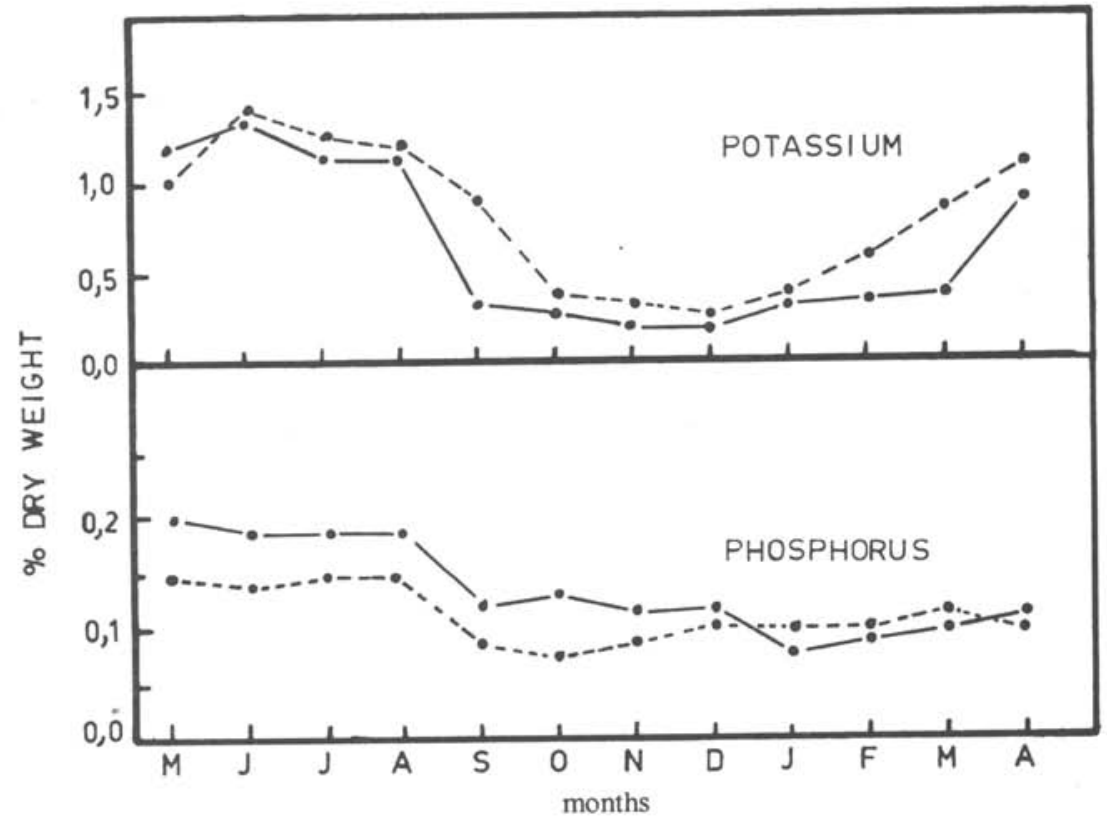

Figure 5. Seasonal variation in percentage of dry weight of potassium and phosphorus in Grateloupia doryphora $(-)$ and in Gymnogongrus griffithsiae ( -...-).

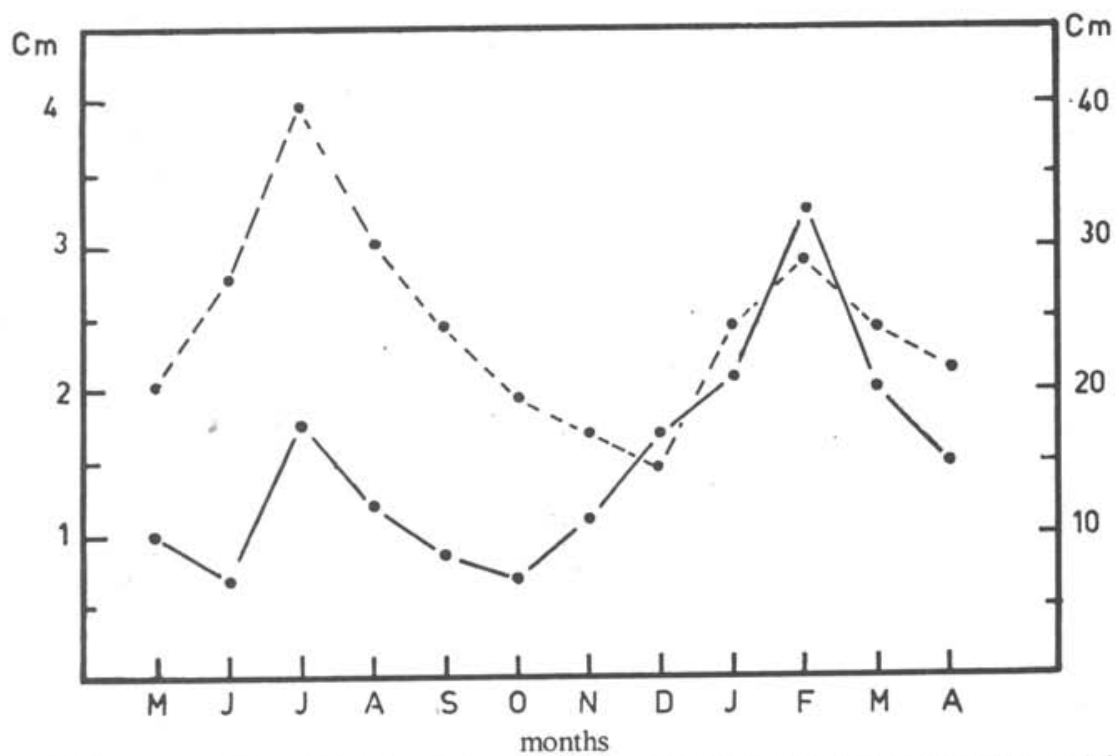

Figure 6. Seasonal variation of Grateloupia doryphora ( $\_$- ) and Gymnogongrus griffithsiae ( - - - ) $)$thalli lenght. 


\section{Discussion}

The Jetty of Rio Grande is placed in an estuarine area, receiving a large volume of water from the Lagoa dos Patos. Therefore, the environmental parameters such as salinity, temperature and dissolved nutrients present marked fluctuations during the year (Kantin \& Baumgarten 1982). The seasonal variation of the thalli length and chemical composition of Grateloupia doryphora and Gymnogongrus griffithsiae are subject to this variation.

Chemical analysis of $G$. doryphora revealed that protein seasonal variations displayed a inverse relation with the thalli length. In winter, a period when the size of the thalli was short and the nitrogenous nutrients were high, an increase of protein algae content was observed. During the spring this species begins to grow, what is characterized by the increase of thalli size, reaching a maximum value in summer. This growth was followed by a decrease in the protein content. A similar relation did not occur in G. griffithsiae, because the maximum size was recorded in winter, coinciding with the highest protein content and nitrogenous nutrients. According to Zavodnik (1973), the decrease in protein content is a growth function of the algae, and the seaweed can accumulate nitrogen at the moment its concentration is high in the environment (Mouradi-Givernaud et al. 1993), and the algae use their nitrogen reserves when there is a drop of this element in the habitat (Chapman \& Craigie 1977; Chapman \& Lyndley 1980).

Generally ammonium and nitrate are the main seaweed nitrogen sources in the natural habitat (Hanisak 1983). Both elements are taken up, but the first one is preferentially absorbed (Haines \& Wheeler 1978; Mizuta \& Maita 1991). In G. doryphora and G. griffithsiae, the protein contents were directly related to the ammonium and, inversely, to the nitrate concentration dissolved in seawater. These results suggest that there was a preferential ammonium utilization by these algae for the protein synthesis. This fact does not mean that the species under study can not also use the nitrate in their metabolism.

In benthic marine algae collected in natural populations and in culture, a maximum carbohydrate concentration occurs when a low level of nitrogen was registered in seawater (Macler \& West 1987; Mouradi-Givernaud et al. 1993). The carbohydrate contents in G. doryphora and G.griffithsiae increased gradually during spring months, becoming more concentrate in the summer. This period was characterized by the drop in nitrogenous nutrients concentration, followed by the increase in salinity, temperature and high light intensity values, which have an influence on the carbohydrate production (Black 1950; Munda \& Kremer 1977).

A negative correlation between the protein and carbohydrates contents in $G$. doryphora and G. griffithsiae was found. The protein/carbohydrate ratio showed values which decreased due to the increase in carbohydrates contents, when the summer approached. As mentioned above, the carbohydrate metabolism was influenced by the physical parameters, while the proteins are related to high nitrogenous nutrients concentrations in the seawater. Thus, the period of active carbohydrate synthesis is characterized by the decrease of protein in the seaweed and reciprocally (Rosenberg \& Ramus 1982; Rotem et al. 1986; Mouradi-Givernaud et al. 1993). 
Lipids content in marine algae is usually low, varying in function of abiotic parameters. Lipids synthesis is stimulated by light; consequently, its percentage decreased with the increase of the immersion depth (Murthy \& Radia 1978). The accumulation of lipids in the algae usually is a response to the nitrogen decrease in the environment (Boney 1966) and the maximum algal growth also leads to the occurrence of the maximum lipids contents (Zavodnik 1973). Although the percentage of lipids in $G$. doryphora did not show a significant variation, maximum values occurred when nitrate and ammonium concentration were lower in the environment. This phenomenon occurred during the summer, when the algae were exposed longer to light in their habitat and the thalli reached the largest size.

The ash content in $G$. doryphora appears inversely proportional to the length of thalli as already described for Gracilaria foliffera var. angustissima (Lapointe 1981) and Gracilaria conferta (Friedlander et al. 1987). In the studied species, a direct relation was found between proteins and ash content, while these two compounds presented an inverse correlation with carbohydrate. It was also observed by Black (1949) in Laminariaceae and suggested that the increase in the photosynthetic rate determines an increase in the carbohydrate contents, and a decrease in ash and protein.

The registered values for phosphorus and potassium in G.doryphora and $G$. griffithsiae were maximum during autumn and winter, following the variation of ash concentration. Both elements showed a negative correlation with $G$. doryphora length thalli. The same correlation was observed with phosphorus, potassium, salinity and temperature available in the environment. These elements are essential macronutrients; therefore, they can be accumulated in winter when the rate of growth is low and can be used during the period when this rate is higher (Rossel \& Srivastava 1984).

\section{Acknowledgments}

I wish to express sincere appreciation to Dr. José Levy Sabaj, who provided invaluable insight and guidance through of this study. I am also grateful to Dr. Eurico Cabral de Oliveira Filho for valuable suggestions on the first version of the manuscript. My best thank is also due to Dr. João Sarkis Yunes for reading the manuscript, making constructive comments, to Prof. Silvia Fresteiro Barbosa and Prof. Maria Mercedes Solis Rivero by the grammatical correction of the text.

\section{References}

A.O.A.C., 1980. Official methods of analysis of the association of official agriculture chemistry. (William Horwitz, Ed.). Washington, D.C. 20044.

Baeza, P. \& Matshuiro, B. 1977. Polysaccharides from Chilean seaweeds IV. A sulfated galactan from Grateloupia lanceolata. Botanica Marina 20(6): 355-357.

Black, W. A. P. 1949. Seasonal variation in chemical composition of some littoral seaweeds common to Scotland. Part II. Fucus serratus, Fucus vesiculosus, Fucus spiralis and Pelvetia canaliculata. Journal of the Society of Chemistry Industrial 68: 183-189.

Black, W. A. P. 1950. The effects of the depth of immersion on the chemical constitution of some sub-littoral seaweeds common to Scotland. Journal of the Society of Chemistry Industrial 69:161-165.

Boney, A. D. 1966. A Biology of Marine Algae. Hutchinson, London. 
Chapman, A. O. R. \& Craigie, J. S. 1977. Seasonal growth in Laminaria longicruris with dissolved inorganic nutrients and internal reserves of nitrogen. Marine Biology 40: 197-205.

Chapman, A. R. O. \& Lindley, J. E. 1980. Seasonal growth of Laminaria solidungula in Canadian High Arctic in relation to irradiance and dissolved nutrient concentrations. Marine Biology 57: 1-5.

Dubois, M.; Guillies, K. A.; Hamilton, J. K.; Rebers, P. A. \& Smith, F. 1956. Colorimetric method for determination of suggar and related substances. Analytical Chemistry 28: 352-356.

Fredriksen, S. \& Rueness, J. 1989. Culture studies of Gelidium latifolium (Grev.) Born et Thurn. (Rhodophyta) from Norway. Growth and nitrogen storage in response to varying photon flux density, temperature and nitrogen availability. Botanica Marina 32(6): 539-546.

Friedlander, M.; Shalev, R.; Ganor, T.; Strimling, S.; Ben-Amotz, A.; Klar, H. \& Wax, Y. 1987. Seasonal fluctuations of growth rate and chemical composition of Gracilaria cf. conferta in outdoor culture in Israel. Hydrobiologia 151/152: 501-507.

Gagné, J. A. \& Mann, K. H. 1981. Comparison of growth strategy in Laminaria populations living under differing seasonal patters of nutrients availibility. International Seaweed Symposium 10: 297-302.

Hanisak, M. D. 1983. The nitrogen relationships of marine macroalgae. Pp. 699-731. In E.J.Carpenter \& D.G. Capone (Ed.), Nitrogen in the Marine Environment. Academic Press, Inc.

Haines, K.C. \& Wheller, P.A. 1978. Ammonium and nitrate uptake by marine macrophytes Hypnea musciformis (Rhodophyta) and Macrocystis pyrifera (Phaeophyta). Journal of Phycology 14: 319-324

Kantin, R. \& Baumgarten, M. G. Z. 1982. Observações hidrográficas no estuário da Lagoa dos Patos: distribuição e flutuaçòes dos sais nutrientes. Atlântica 5(1): 76-92.

Lapointe, B. E. 1981. The effects of light and nitrogen on the growth, pigment content and biochemical composition of Gracilaria foliifera v. angustissima (Gigartinales, Rhodophyta). Journal of Phycology 17: 90-95.

Macler, B. A. \& West, J. A. 1987. Life history and physiology of red algae Gelidium coulteri, in unialgal culture. Aquaculture 61: 281-293.

Macler, B. A. \& Zupan, J. R. 1991. Physiological basis for the cultivation of Gelidiales. Hydrobiologia 221: 83-90.

Mizuta, H. \& Maita, Y. 1991. Effects of nitrate supply on ammonium assimilations in the blade of Laminaria japonica (Phaeophyceae). Bulletin of Faculty Fisheries Hokkaido University 42(3): 107-114.

Mouradi-Givernaud, A.; T. Givernaud, Y.; Morvan, H. \& Cosson, J. 1992. Agar from Gelidium latifolium (Rhodophyceae, Gelidiales), biochemical composition and seasonal variations. Botanica Marina 35: 153159.

Mouradi-Givernaud, A.; T. Givernaud, Y.; Morvan, H. \& Cosson, J. 1993. Annual variations of the biochemical composition of Gelidium latifolium (Greville) Thuret et Bornet. Hidrobiologia 260/261: 607-612.

Mshigeni, K. E. 1979. The economic algal genus Eucheuma (Rhodophyta, Gigartinales): Observation on the morphology and distribution ecology of Tanzanian species. Botanica Marina 22: 437-445.

Munda, I. M. \& Kremer, B. P. 1977. Chemical composition and physiological properties of fucoids under conditions of reduced salinity. Marine Biology 42: 9-15.

Murthy, M. S. \& Radia, P. 1978. Eco-biochemical studies on some economical important intertidal algae from Port Okha (India). Botanica Marina 24: 417-422.

Ohlweiler, O. A. 1974. Química Analítica Quantitativa. Livros Técnicos e Cientificos, Rio de Janeiro.

Rosenberg, G. \& Ramus, J. 1982. Ecological growth strategies in the seaweeds Gracilaria follifera (Rhodophyceae) and Ulva sp. (Chlorophyta): Soluble nitrogen and reserves carbohydrates. Marine Biology 66: $251-259$.

Rossel, K. G. \& Srivastava, L. M. 1984. Seasonal variation in the chemical constituents of brown algae Macrocystis integrifolia and Nereocystis hetkeana. Canadian Journal of Botany 62: 2229-2236.

Rotem, A.; Roth-Bejerano, N.\& Arad, S. M. 1986. Effect of controlled environmental conditions on starch and agar contents of Gracialaria sp. (Rhodophyceae). Journal of Phycology 22: 117-121.

Saito, R. M. \& Oliveira F ${ }^{\circ}$, E.C. de 1990. Chemical screening of Brazilian marine algae producing carrageenans. Hydrobiologia 204/205: 585-588.

Salinas, J. M. \& Valdés, L. 1993. Influence of temperature and photoperiod on the re-attachment process of Gelidium sesquipedale (Clem.)Born. et Thurn. (Gelidiales:Rhodophyta). Journal of Applied Phycology 5: $317-326$.

Santelices, B., 1991.Production ecology of Gelidium. Hydrobiologia 221: 31-44.

Solorzano, L. 1969. Determination of ammonia in natural waters by phenohypoclorite methods. Limnology Oceanography 14: 799-801. 
Standard methods: for examination of water and wastewater, 1989. Vanadomolybdo-phosphoric Acid Colorimetric Method 4500-PC. Pp. 4-112. In L.S. Clesceri; A. E. Greenberg \& R. Trussell ( Ed.), $17^{\text {th }}$ Edição. American Public Health Association, Washington.

Strickland, J. D. H. \& Parson, T. R. 1972. A practical handbook of seawater analysis. Fish Research Board Canadian Bulletin 167: 1-310.

Vergara, J. J.; Niell, F. X. \& Torres, M. 1993. Culture of Gelidium sesquipedale(Clem.) Born. et Thurn. in chemostat system. Biomass production and metabolic responses affected by $\mathrm{N}$ flow. Journal of Applied Phycology 5: 405-415.

Zavodinik, N. 1973. Seasonal variations in rate of photosynthetic activity and chemical composition of the littoral seaweeds common to North Adriatic.Part I.Fucus virsoides (Don) J.Ag. Botanica Marina 16: 155-165. 